\title{
THE PREVALENCE OF INTESTINAL PROTOZOA IN NAIVASHA, KITUI, MACHAKOS, TAVETA AND NANDI HILLS AREAS IN KENYA*
}

\author{
Motohiro Iseki ${ }^{1}$, Kaoru Hayashi ${ }^{2}$, Simon M. Gatika ${ }^{3}$ \\ AND T. K. Arap Siongok ${ }^{3}$ \\ Received July 181983 / Accepted October 11983
}

\begin{abstract}
During the period from May to November in 1980, a total of 2,114 stool specimens were collected from individuals living in Naivasha, Kitui, Machakos, Taveta and Nandi Hills areas in Kenya, and they were examined for intestinal protozoa by formol-ether concentration method followed by idoine-staining.

Out of 2,114 specimens $673(31.8 \%)$ were positive for Entamoeba histolytica, 1,105 (52.3\%) for Entamoeba coli, 102 (4.8\%) for Endolimax nana, 184 (8.7\%) for Iodamoeba bütschlii, $176(8.3 \%)$ for Giardia lamblia, and $220(10.4 \%)$ for Chilomastix mesnili. The total positive rate, which means the percentage of positive persons for any kinds of intestinal protozoa, was 75.1 per cent.
\end{abstract}

\section{INTRODUCTION}

In developing countries in tropical area, the health of people and the socio-economical development have been seriously damaged and hampered by parasitic diseases. The same is true in Kenya. Malaria, trypanosomiasis, leishmaniasis and other helminthic diseases are widespread. For the purpose of controlling these parasitic diseases many researchers in KEMRI (Kenya Medical Research Institute), KETRI (Kenya Trypanosomiasis Research Institute), DDC \& R (Division of Disease Control and Research, Ministry of Health), ICIPE (International Center of Insect Physiology and Ecology), University of Nairobi and some other laboratories have made various efforts. However, there have been few reports relating to the epidemiological survey on the intestinal protozoa in Kenya.

The infection of intestinal protozoa, including some medically important species such as Entamoeba histolytica and Giardia lamblia, occurs through the intake of food and water contaminated with the faecal material containing protozoal cysts. Therefore, the incidence of intestinal protozoa in a certain area may indicate the level of sanitary conditions in the respective area.

1 Department of Medical Zoology, Osaka City University Medical School, Osaka 545, Japan. 2 Department of Virology, Institute for Tropical Medicine, Nagasaki University, Nagasaki 852, Japan. 3 Division of Disease Control and Research, Nairobi, Kenya.

* This work was carried out under the Communicable Disease Research and Control Project of KenyaJapan Medical Cooperation Program, supported by the Japan International Cooperation Agency, started in 1979. 
In this report, the authors present the result of stool examinations carried out in several areas of Kenya during the period from May to November in 1980. The objective was to make clear the prevalence of intestinal protozoa in Kenya and to provide with a guide in planning the communicable disease control program by the Government of Kenya.

\section{Materials ANd Methods}

A total of 2,114 stool specimens were collected from individuals living in Naivasha, Kitui, Machakos, Taveta and Nandi Hills during the period from May to November in 1980. Most of specimens were originally collected for the study of schistosomiasis by the staff members of Division of Disease Control and Research (DDC \& R), Ministry of Health, Nairobi. The location where this survey was conducted is shown in Figure 1. The number of specimens and the type of population in each location are shown in Table 1.

The stool specimens were emulsified in 10 per cent formol-saline at each location, and transported to the laboratory of DDC \& R, Nairobi. After the helminthic ova examination, the specimens were used for the present study. They were examined by formol-ether concentration method followed by iodine-staining.

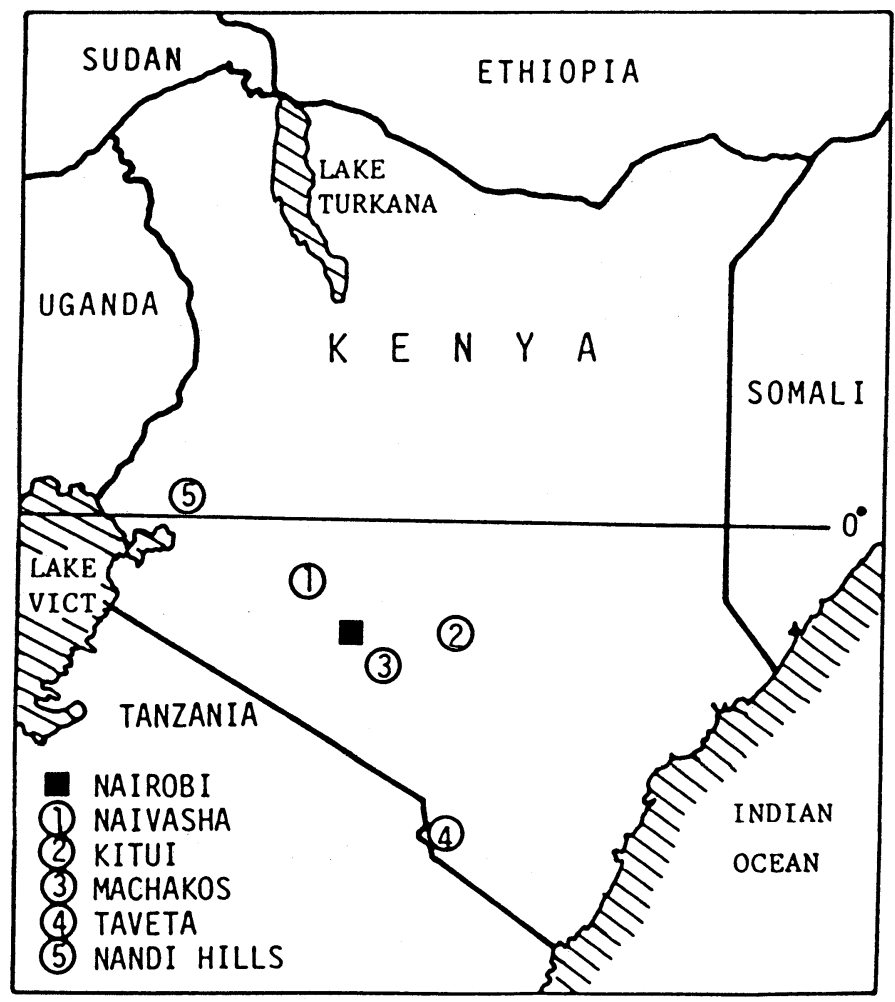

Figure 1 Map of Kenya showing locations where this survey was conducted. 
Table 1 Stool specimens examined

\begin{tabular}{llc}
\hline Location & \multicolumn{1}{c}{ Type of population } & $\begin{array}{c}\text { Number of } \\
\text { specimen }\end{array}$ \\
\hline Naivasha & Farmers and their families & 276 \\
Kitui & General inhabitants & 980 \\
Masinga & & \\
Migwani & & \\
Mutonguni & Primary school children & 780 \\
Machakos & & 43 \\
Kangundo & General inhabitants & 35 \\
Taveta & Primary school children & 2,114 \\
Nandi Hills & & \\
\hline Total & &
\end{tabular}

\section{RESULTS}

The prevalence of Entamoeba histolytica, Entamoeba coli, Endolimax nana, Iodamoeba bütschlii, Giardia lamblia and Chilomastix mesnili in each location is shown in Table 2. The infection rates of E. histolytica, E. coli, G. lamblia and $C$. mesnili by age and by sex are shown in Table 3 and Table 4 respectively.

The results are summarized as follows;

\section{E. histolytica}

Out of 2,114 specimens examined $673(31.8 \%)$ were positive for this parasite. The highest positive rate was 35.1 per cent in Machakos and the lowest was 27.9 per cent in Taveta. By age, the lowest positive rate, 20.0 per cent, was seen in the youngest age group ( $0-4$ years old). The rates gradually increased up to the middle age group and, thereafter, declined slightly. The highest positive rate appeared in the age group of 40-49 years old. The infection rates in the male and female were 27.8 per cent and 32.5 per cent respectively, but there was no

Table 2 Prevalence of intestinal protozoa in Naivasha, Kitui, Machakos, Taveta and Nandi Hills

\begin{tabular}{|c|c|c|c|c|c|c|c|c|}
\hline \multirow{2}{*}{ Location } & \multirow{2}{*}{$\begin{array}{c}\text { Number } \\
\text { exam- } \\
\text { ined }\end{array}$} & \multicolumn{6}{|c|}{ Percentage of infection } & \multirow{2}{*}{$\begin{array}{c}\text { Total } \\
\text { positive } \\
\text { rate }(\%)\end{array}$} \\
\hline & & E. hist. & E. coli & E. nana & I. büts. & G. lamb. & C. mesn. & \\
\hline Naivasha & 276 & 34.1 & 44.2 & 2.9 & 5.8 & 5.6 & 22.5 & 75.0 \\
\hline Kitui & 980 & 28.8 & 46.4 & 5.0 & 9.0 & 7.9 & 9.6 & 70.6 \\
\hline Machakos & 780 & 35.1 & 63.3 & 4.7 & 9.2 & 10.0 & 7.4 & 81.4 \\
\hline Taveta & 43 & 27.9 & 51.2 & 2.3 & 11.6 & 2.3 & 2.3 & 64.0 \\
\hline Nandi Hills & 35 & 31.4 & 34.3 & 20.0 & 8.6 & 17.1 & 14.3 & 74.3 \\
\hline Total & 2,114 & 31.8 & 52.3 & 4.8 & 8.7 & 8.3 & 10.4 & 75.1 \\
\hline
\end{tabular}


Table 3 Infection rates of intestinal protozoa among various age groups in Naivasha and Kitui

\begin{tabular}{cccccc}
\hline \multirow{2}{*}{$\begin{array}{c}\text { Age } \\
\text { group } \\
\text { (years) }\end{array}$} & Number & \multicolumn{5}{c}{ Percentage of infection } \\
\cline { 3 - 6 } examined & & E. hist. & E. coli & G. lamb. & C. mesn. \\
\hline $0-4$ & 125 & 20.0 & 26.4 & 16.8 & 6.4 \\
$5-9$ & 321 & 25.5 & 42.4 & 10.0 & 10.6 \\
$10-14$ & 243 & 34.6 & 46.1 & 8.2 & 13.2 \\
$15-19$ & 135 & 33.3 & 50.4 & 5.2 & 13.3 \\
$20-29$ & 151 & 35.8 & 55.6 & 5.3 & 12.6 \\
$30-39$ & 103 & 30.1 & 57.3 & 1.9 & 16.5 \\
$40-49$ & 64 & 43.8 & 64.0 & 1.6 & 15.6 \\
$50-59$ & 46 & 30.4 & 54.3 & 2.2 & 21.7 \\
$60-69$ & 34 & 32.4 & 58.8 & 2.9 & 20.6 \\
$70-$ & 22 & 22.7 & 54.5 & 0 & 13.6 \\
\hline Total & 1,244 & 30.4 & 46.9 & 7.3 & 12.9 \\
\hline
\end{tabular}

Table 4 Infection rates of intestinal protozoa by sex in Naivasha and Kitui

\begin{tabular}{lccccc}
\hline \multirow{2}{*}{ Sex } & \multirow{2}{*}{$\begin{array}{c}\text { Number } \\
\text { examined }\end{array}$} & \multicolumn{4}{c}{ Percentage of infection } \\
\cline { 3 - 6 } & 564 & E. hist. & E. coli & G. lamb. & C. mesn. \\
\hline Male & 680 & 32.5 & 50.7 & 7.4 & 14.4 \\
Female & 68.4 & 42.4 & 7.3 & 11.0 \\
\hline
\end{tabular}

statistically significant difference detected between them by $\mathrm{X}^{2}$-test.

E. coli

E. coli was the most common species among the intestinal protozoa detected, and evenly widespread in each location. The highest infection rate was 63.3 per cent in Machakos and the average in five locations was 52.3 per cent. The change of its infection rate by age showed the same tendency as the case of $E$. histolytica. The infection rate in female, 50.7 per cent, was higher than in male, 42.4 per cent. This difference is statistically significant $(\mathrm{P}<0.01)$ in $\mathrm{X}^{2}$-test.

\section{E. nana and I. bütschlii}

Positive rates of these two species were rather low. The average rates in five locations were 4.8 per cent for $E$. nana and 8.7 per cent for I. bütschlii respectively.

\section{G. lamblia}

The average positive rate for this parasite was 8.3 per cent. The highest rate, 16.8 per cent, was seen at the youngest age group. The rate gradually declined as the host ages became older, and especially it became extremely low at the age of 30 onward. There was no significant difference in the infection rates between the male and female in $\mathrm{X}^{2}$-test. 


\section{C. mesnili}

The highest, the lowest and the average positive rates for this species were 22.5, 2.3 and 10.4 per cent respectively. The lowest positive rate among age groups was 6.4 per cent in the youngest age group. Among other age groups and between the male and female there was no significant difference in the infection rate.

Total positive rate

The total positive rate, which means the percentage of infected persons with any kinds of intestinal protozoa, was 75.1 per cent on the average. The highest one was 81.4 per cent in Machakos and the lowest one was 60.0 per cent in Taveta.

Other intestinal protozoa detected

Entamoeba hartmanni and Trichomonas hominis were detected in a few cases, but Balantidium coli and isosporan oocysts were not detected.

\section{Discussion}

The Republic of Kenya stands almost exactly astride the Equator. However, the climate of all the locations where this survey was conducted is different from the normal limits of the textbook type of an equatorial region with its high temperature, high humidity, thick forests and heavy rainfall. The locations, except Taveta, lie on the highlands of this country. Their actual altitudes are between 1,000-2,000 m. In Nairobi, for example, temperatures are as follows; absolute maximum: $29.7^{\circ} \mathrm{C}$, mean maximum: $23.6^{\circ} \mathrm{C}$, mean minimum: $11.6^{\circ} \mathrm{C}$, and absolute minimum: $2.5^{\circ} \mathrm{C}$. The relative humidity at $3 \mathrm{p} . \mathrm{m}$. in Nairobi, is about 50 per cent, and the mean annual rainfall is 750 to $1,000 \mathrm{~mm}$. In Kenya there are two main rainy seasons; the long rains from March to May and the short rains from November to December. The climate of Naivasha, Kitui, Machakos and Nandi Hills is roughly the same as of Nairobi. Taveta locates at the foot of Mt. Kilimanjaro, near Kenya-Tanzania border, and its altitude is about $500 \mathrm{~m}$. Therefore, the annual mean temperature is a little higher than other locations.

The inhabitants of these locations are mainly engaged in maize, wheat, cotton, sugar, banana and, partly in Taveta, sisal production.

The stool specimens for this survey were collected from May in the long rains, through the dry season, to November in the short rains. The main purpose of this work was to make the prevalence of intestinal protozoal infections clear in each locations. Therefore, analysis of the seasonal results was not done.

Althogh the iron hematoxylin staining or the trichrome staining method is recomended for the identification of amoeba species, the formol-ether concentration method followed by iodine staining was carried out in this work. Because, all the specimens had been fixed in 10 per cent formol-saline at each location for the purpose of the detection of schistosoma eggs prior to the examination of protozoa.

The results show that the intestinal protozoal infection is widespread in Kenya. About 75 per cent of specimens examined were positive for one or more protozoal 
species. It is noticeable that a considerable number of children less than 5 years old has already been highly infected. This result was obtained from a single examination per person. As an infected patient does not always discharge cysts, the actual positive rate should be higher than this result in reality.

Among the intestinal protozoa detected the most common species was $E$. coli followed by E. histolytica, C. mesnili and G. lamblia. The life cycle of these parasites is rather simple. The infective cysts, which are resistant to environmental changes, are passed out in the faeces of infected persons, and then they are ingested by a new host. Drinking water and food, therefore, are most likely highly contaminated with faecal materials in the locations where this work was conducted.

Odhiambo and Konyango (1980) reported the prevalence of intestinal protozoa in an urban situation in Kisumu Municipality near Lake Victoria in Kenya, they stated that out of 1,432 stool specimens $338(26.3 \%)$ were positive for amoebic infection. Kamunvi and Situbi (1981) reported the prevalence of intestinal protozoa in rural communities in South Nyanza, Kisumu Municipality. They showed that out of 906 patients 26.7 per cent were positive for E. histolytica, and 31.6 per cent for E. coli. As the stools were examined by direct method in these two surveys, the positive rates in their data might be lower than the rate obtained by concentration method as shown in the present data.

As our results and these two reports show, it is clear that E. histolytica infection is widespread in Kenya. And, as Rees et al. (1974) has already pointed out, amoebic dysentery and amoebic liver abscess are also not uncommon problem in Kenya, although the incidence of these invasive amoebiases are not clear both in the country as a whole and in individual districts.

For the prevention and control of these parasitic diseases, it is important to promote (1) the mass-survey and treatment, (2) improvement of sanitary environment, (3) education of hygiene for school children and, finally, (4) massive campaign against parasitic diseases for general public.

These parasite control measures gave a good successful result in Japan. Morishita (1975) described on it, an excerpt of which is as follows;

The parasitic infection was originally quite common in Japan. Indeed, the result of the stool examination carried out during 1922-1926 showed that out of 1,157,322 specimens 709,438 (61.3\%) were positive for Ascaris, 269,656 (23.3\%) for hookworm, and the total egg positive rate was 73.8 per cent. Though its incidence declined year by year until the Second World War, its infection occured explosively after the War. In 1950, the total egg positive rate in 7,026,499 specimens examined rose again to 63.8 per cent. Then the national attention focussed to this problem and the nationwide parasite control activities started. Besides the Health Center's activity, the Japan Association of Parasite Control was organized and its activities started in many Prefectures in 1949. The juridical ground of the parasite control activities in Japan is 'The Parasite Control Act (1931)'. Since the parasite infection after the last War became a serious public health problem, the Ministry of Health and Welfare stipulated in order to clarify the details of control operation. They were: 'General Essentials of Parasite Control (1959)', 'Essentials of Mass-Treatment of Ascaris and Hookworm Infection (1960)', and 'Mass-Treatment of Pinworm Infection 
(1960)' etc. 'School Hygiene Act (1958)' enacted by the Ministry of Education stipulated that primary, secondary and high school pupils should undergo examination for Ascaris and hookworm at least once a year. In 1960 the Act was partly revised to include all kinds of parasites found in pupils' stool examination. Since these operations started, the incidence of all kinds of parasites has been remarkably reduced year by year. In 1965, the result of the stool examination on 12,720,315 specimens showed that the total egg positive rate became 8.7 per cent. And, at last, the rate fell to 0.49 per cent in 1980 .

Among several Asian countries, The Asian Parasite Control Organization was founded and its cooperative activities started in 1974. Good results have been accumulating in these member countries.

Also in African countries including the Republic of Kenya, the soil-transmitted parasite is a quite big problem as well as the vector born parasite such as Plasmodia and Schistosome. The most important measure for the control of parasitic diseases must be the mass-survey and the mass-treatment. For performing this operation, a suitable system and actual Acts should be prepared.

Though it may take a long period of time and require intensive efforts to control the parasitic diseases, it can be done with satisfactory results as proven in Japan.

\section{ACKNowledgement}

We wish to thank Mr. M. Masika, a laboratory assistant, and other staff members of the Helminthology Section of DDC \& R, Nairobi, for their warm cooperation in performing this investigation.

\section{REFERENCES}

1) Kamunvi, F. and Situbi, A. P. (1981): A pilot study of the prevalence of human intestinal protozoa among patients attending rural health units in South Nyanza, 2nd Annual Medical Conference of Kenya Medical Research Institute and Kenya Trypanosomiasis Research Institute, Nairobi

2) Morishita, K. (1975): The Japan Association of Parasite Control and its activities, The Japan Association of Parasite Control, Tokyo

3) Odhiambo, J. and Konyango, M. (1980): Study on the prevalence of intestinal protozoa in Kisum Municipality, 1st Annual Medical Conference of Kenya Medical Research Institute and Kenya Trypanosomiasis Research Institute, Nairobi

4) Rees, P. H., Mngola, E. N., O’leary, P. and Pamba, H. O. (1974): Vogel, L. C., Muller, A. S., Odingo R. S., Onyango, Z. and Geus, A. D. (ed) Health and sisease in Kenya, 339-346, East. African Literature Bureau, Nairobi 


\title{
ケニア諸地域住民の腸管寄生原虫感染状況
}

\author{
井関基弘 ${ }^{1} \cdot$ 林 董 $^{2} \cdot \operatorname{SiMON}$ M. GATIKA ${ }^{3}$
}

T. K. Arap Siongok ${ }^{3}$

1980年 5 月から11月の間にケニアの Naivasha, Kitui, Machakos, Taveta 及び Nandi Hills の住民 2,114 人から採取した翼便についてホルマリン・エーテル法により腸管寄生原虫のシストの検査を行 い感染状況を調查した。

その結果, 赤刭アメーバは $31.8 \%$, 大腸アメーバは $52.3 \%$ と極めて高率を示し，その他は小形ア

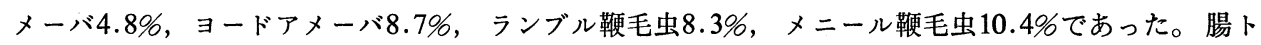
リコモナス及び Entamoeba hartmanni あ少数例検出されたが，大腸バランチジゥムやイソスポーラ などは検出されなかった。総陽性率（陽性総数/検查総数）は75.1\%にあ及び，领料水，食物など生 活環境が䔬便によって高度に污染されていることが示唆された。陽性率に男女間の有意差は認められ なかった。年跉別にみると，4歳以下の乳幼児でもすでにかなり高率に感染がみられるが， ランブル 鞭毛虫を除き, 特に30歳代から40歳代で最高值を示した。ランブル鞭毛虫は若年齢層ほど高い陽性率 を示し，4歳以下が最高であった。

本調査は日本国際協力事業団 (JICA) の医療協力「ケニア伝染病研究対策プロジェクト」の一環と して行われたものであり，その撲滅対策を，戦後日本で実施され成果をあげた寄生虫予防対策事業と の関連において考察した。

1 大阪市立大学医学部医動物学教室 2 長崎大学熱帯医学研究所ウイルス学部門 (現在 : 大分県公害 衛生センター） 3 ケニア共和国保健省 